\title{
Vidnesbyrd fra neden - Bliktrommen
}

\author{
... menneskelig, det vil sige barnlig, \\ nysgerrig, dobbeltbundet, umoralsk.
}

\section{$I$}

I Becketts Slutspil spørger Hamm Clov, hvordan det ser ud udenfor. Svaret er: Gråt!

Günter Grass citerer i sin Frankfurter-forelæsning fra 1990, „Om at skrive efter Auschwitz«, et af sine egne digte, "Askese«, hvor en række regler formuleres for digtets »du«, dvs. blandt andre Grass selv. Den afgørende regel er: „Du skal elske farven grå. « ${ }^{1}$ Grass og mange af hans samtidige opfattede Adornos bemærkning om at skrive efter Auschwitz som prohibitiv, som en art skriveforbud. Den stod i Adornos artikel om »Kulturkritik og samfund«i 1949: »Kulturkritikken finder sig selv over for det sidste trin af dialektikken mellem »kultur og barbari: at skrive et digt efter Auschwitz er barbarisk, og det angriber også den erkendelse, der udsiger, hvorfor det blev umuligt at skrive digte idag. $\|^{2}$ Digtet "Askese« var en slags svar: der skulle skrives, der skulle skabes kunst (Grass er også grafiker, så farven grå er noget meget konkret for ham), men det skulle ske inden for bestemte grænser. Det var ikke farverige skildringer af omverdenen eller spektakulære indrepsykiske forhold, der var behov for: gråt snarere end farverigt; ej heller var der behov for absolutte oppositioner, hverken hvidt eller sort: „Det var nødvendigt at gøre sig fri af absolutte målestokke, ideologisk hvidt eller sort, at afskrive trossætninger og kun satse på tvivl, der gjorde alt, selv regnbuen,

1. Günter Grass: Der Autor als fragwürdiger Zeuge, München 1997, p. 202. Herefter forkortet AafZ.

2. Adorno, Theodor W.: "Kulturkritik og samfund«, in Adorno: Kritiske modeller, København 1971, p. 29. 
grålig« (AafZ, p. 204). Men det betød ikke, at den tyske fortid skulle forblive i det dunkle: "Jeg var provokeret af dæmoniseringen af National-Socialismen, som var vidt udbredt dengang, ja, ligefrem en officiel regerings-opfattelse - jeg ønskede at sætte klart lys på forbrydelserne, bringe dem ud i dagslyset«(AafZ, p. 212).

Grass skrev Bliktrommen i Paris og blev blandt andet hjulpet af samtaler med Paul Celan:

"han forstod før jeg gjorde det, at der måtte pilles lag efter lag af det profane episke løg, og at jeg ikke skulle tage fri fra den opgave. Han gav mig mod til at bringe fiktive figurer som Fajngold, Sigismund Marcus og Eddi Amsel ind i mit småborgerlige roman-univers, dvs. ikke ædle, men ordinære og ekcentriske jøder. (...) Hans hjælp var ikke direkte, men skjult i sidebemærkninger, f. eks. under spadsereture i parker« (ibid.).

Kontrasten mellem de to forfattere er slående, så meget desto mere bemærkelsesværdigt er deres frugtbare samspil. „Hvorfor Celan, for hvem ordene hen mod slutningen af halvtredserne blev stadigt knappere og hvis sprog og tilværelse bevægede sig mod indsnævring, Engführung?«-spørger Grass, og hans svar er: "Jeg ved det ikke« (ibid.).

På den ene side Slutspil og "Engführung«, på den anden side Bliktrommen: Når det gælder litterær form kunne afstanden næppe være større, men den historiske situation var den samme (hvis man kan tale om en historisk situation i almindelighed), og engagementet gjaldt det samme: den nære fortid og dens betydning for samtiden.

\section{II}

Bliktrommen blev offentliggjort i 1959, men havde været undervejs igennem adskillige år. En af de oprindelige ideer var til stede i et tidligt digt af Grass der, ejendommeligt nok, handlede om en søjlehelgen. En ung mand - jeg følger Grass' summering af digtet $)^{3}$ - en eksistentialist i tidens stil, har bygget en søjle midt i sin lille hjemby. Fra sin ophøjede position kan han se ned på sine medborgere og indtage sin ret statiske position. Digtet var ikke godt, forsikrer Grass os, men det repræsenterede et skridt på vejen til etableringen af en forskudt synsvinkel. Samme år, dvs. i 1952, så han tilfældigt i en restaurant en treårig dreng med en bliktromme: »Jeg blev slået af og erindrede den selvforglemmende hengivelse til instrumentet, men også hvordan han samti-

3. Grass: »Rückblick auf die Blechtrommel«, in AafZ, pp. 105-6. 
dig ignorede de voksnes verden (eftermiddagens småpludrende kaffedrikkere)«(AafZ, pp. 105-6). Igennem de følgende år skrev Grass en række korte enaktere og balletlibrettoer (hans kone var danserinde) med stof, som senere indgik i Bliktrommen. Han påbegyndte også en roman, et projekt som imidlertid ikke rigtig fungerede.

Da han var flyttet til Paris sammen med sin kone kæmpede han så med en roman, der skiftevis hed »Trommeslageren Oskar«, »Trommeslageren« og »Bliktrommen«. Tre versioner endte i ovnen.

Der var således tale om en heterogen mængde af tilløb, fragmenter, tilskyndelser og inspirationer. Søjlehelgenens forskudte synsvinkel var blevet til den trommende drengs, blikket var fortsat forskudt, men nu fra neden, ikke den højt hævede, overlegne yngling, men det lille barn som vidne til verdens gang. Dermed var den afgørende synsvinkel etableret. Det var imidlertid, beretter Grass selv, formuleringen af den indledende sætning, der for alvor satte gang i arbejdet med den endelige version af romanen: „Jeg må bekende, at jeg er patient på en anstalt for sindslidende...«-»Zugegeben: ich bin Insasse einer Heil- und Pflegeanstalt...« Grass giver følgende malende beskrivelse af, hvordan denne situering af Oskar som fortæller åbnede for det videre arbejde:

»Med den første sætning [...] faldt blokeringen, trængte sprog sig på, løb erindringsformåen og fantasi, legende lyst og detaljeoptagethed rask afsted, fulgte kapitel efter kapitel, sprang jeg, hvor huller hæmmede fortællings strøm, kom historier med lokale tilbud mig i møde, [...] lugte blev frisat, jeg lagde mig en vildtvoksende familie til, jeg kæmpede med Oskar Matzerath og hans tilbøjelighed for sporvogne og deres linieføring, om samtidige begivenheder og kronologiens absurde tvang, om det berettigede i at Oskar fortalte i første person, om hans fordring på at ville have en søn, om hans virkelige skyld og om hans fingerede skyld« (AafZ, p. 108).

Det som her blev frisat, var ikke en asketisk tilgang til at skrive litteratur efter Auschwitz, Bliktrommen er ikke blot nuancer i gråt, den er tværtimod en uhyre farverig roman. For så vidt modificerede Grass sit tidligere princip, men den anden side af princippet om at holde sig til det grå blev opretholdt: Bliktrommen er ikke en sort-hvid roman i moralsk forstand. Det har netop at gøre med fortællerens position. I dobbelt henseende: For det første giver Oskars position som barn ham perspektivet fra neden, der giver anledning til at bryde overfladeforholdene mellem de voksne personer op. For det andet placerede romanens første sætning ham som førstepersons-fortcller, således at netop hans synsvinkel bliver den afgørende i skildringen af omverdenen 
og voksenverdenen. Men hertil kommer det tredje moment: at han skriver i en bestemt situation, nemlig som ufrivilligt indsat i en anstalt. Det giver ham ikke netop troværdighed. De historier, som han fortæller til sin plejer og overvåger, Bruno, er - ifølge Oskar selv - "vorgelogen«, fremløjet, "skrøner«. Alle disse forhold er anslået i den indledende sætning.

Hans situation på hospitalet er ret speciel. Skønt han ønsker at isolere sig, har han besøg hver uge.

"En gang om ugen afbryder en besøgsdag min stilhed, der er flettet mellem hvide metalstænger. Så kommer de, der vil redde mig, som morer sig med at holde af mig, de, der gerne vil agte, påskønne og lære sig selv at kende i mig. Hvor blinde, nervøse og uopdragne de dog er! De kradser med deres neglesakse på mit hvidlakerede sengegitter og gnidrer med deres kuglepenne og blyanter langstrakte, uanstændige figurer på lakken. [...] efter at det er lykkedes dem at overbevise mig, som de utrætteligt vil redde, om deres næstekærligheds høje standard, glæder de sig på ny over deres egen tilværelse og forlader mig. $\star^{4}$

Kort sagt: efter at de har overbevist Oskar om, hvor gode de er, kan de lide sig selv igen, det er deres måde at lære sig selv at kende på gennem Oskar. Men igennem denne ironiske markering af forholdet mellem Oskar og hans medmennesker er også effekten af hans skriveri antydet: den kan fremme læsernes selverkendelse. Karakteren af dette skriveri antydes gennem historien om, hvordan han fik papir at skrive på:

"Da jeg sagde til Bruno: "Åh, Bruno, ville du ikke nok købe fem hundrede ark uskyldigt papir til mig?« svarede Bruno, mens han kiggede op i loftet og rakte pegefingeren i samme retning, som om han ville udfordre til en sammenligning: »De mener hvidt papir, Hr. Oskar?»

Jeg blev ved det lille ord "uskyldigt« og bad Bruno om også at sige sådan i butikken. Da han sent på eftermiddagen kom tilbage med pakken, ville han give mig indtryk af en meget tankefuld Bruno. Flere gange og vedvarende stirrede han op mod loftet, fra hvilket han hentede alle sine inspirationer, og udtalte lidt efter: "De anbefalede mig det rigtige ord. Jeg bad om uskyldigt papir, og ekspeditricen rødmede stærkt, inden hun kom med det, jeg havde bedt om« (pp.12-13).

4. Günter Grass: Bliktrommen, København 1999, pp. 11-12. Hvor intet andet er anført, henvises i det efterfølgende til denne udgave. 
Dette lader naturligvis ikke nogen tvivl tilbage om, at deflorering er den implicerede association, dvs. at tab af uskyld er effekten af Oskars skrift potentielt i al fald. Og tab af uskyld er jo i vores kultur uløseligt knyttet til at opnå viden, kundskab. Når man tager bogens stof i betragtning er dette ikke blot en vits, det er den dybt alvorlige hensigt med bogen, der er på tale.

At Oskars virksomhed har at gøre med selverkendelse, med at bibringe hans medmennesker en selvindsigt, de ellers ikke ville få, det er der et tydeligt - omend tvetydigt - eksempel på i kapitlet om »Udstillingsvinduer«, hvor det er hans evne til at skære i glas, der er på tale. Både hans stemme og hans tromme har et moment af kunstnerisk virksomhed, som sætter dem parallelt med hans skrift. Udstillingsvinduerne udsættes for Oskars skærende røst, således at små runde huller åbner sig mellem betragteren udenfor og den genstand, han eller hun betragter. Et greb igennem hullet og man har fat i genstanden. Denne forførelseskunst, som Oskar også kalder det, er uimodståelig, betragterne lærer nye sider af sig selv at kende. Oskar reflekterer:

"Hvis De spørger mig: var det det Onde, der befalede Oskar at forøge den i forvejen stærke fristelse ved en velpudset vinduesrude ved at skabe en åbning på størrelse med en hånd, må jeg svare: Ja, det var det Onde. [...] På den anden side må jeg [...] sige til mig selv og min plejer Bruno: Du har ikke blot opfyldt de små og mellemstore ønsker for alle de stilfærdige og i ønskeobjekter forelskede spadserende, men du har også hjulpet menneskene foran udstillingsvinduerne til at kende sig selv« (p. 118).

\section{III}

Men tilbage til begyndelsen: på de første sider efter introduktionen til Oskars situation avles Oskars mor. Hans bedstemor, Anna Bronski, sidder med sine fire kartoffelfarvede skørter på en kartoffelmark, da hans bedstefar dukker op: i sit forsøg på at skjule sig for sine forfølgere kryber han ind under hendes skørter, og resultatet er Oskars mor - »stille var det som på den første dag eller på den sidste, en smule vind blafrede i bålet, telegrafstolperne talte lydløst hverandre, teglværkets skorsten stod rank, og hun, min mormor, hun strøg det øverste skørt over det andet skørt, glat og fornuftigt, mærkede ham knap under det fjerde skørt og havde med sit tredje skørt endnu ikke fattet, hvad der føltes nyt og forbavsende for hendes hud« ( $B$, p. 17) Oskar begynder således virkelig med begyndelsen - ob ovo, om man vil , da han fortæller sin historie til »alle dem, der uden for min anstalt for sindslidende må føre et forvirret liv« (p. 13). 
Det er på afstand af dette mudrede liv, Oskar skriver. Det er også på afstand i tidslig forstand: hans beretning er retrospektiv, samtidig med at han fortæller sine læsere, hvad der går for sig i hans umiddelbare liv i de år, hvor han skriver (i overensstemmelse med princippet i Sternes Tristram Shandy). På sin tredive års fødselsdag når han det punkt i sin beretning, hvor han bliver indsat i anstalten. Og så er der ikke mere at fortælle - han har nået den alder, hvor man formodes at være moden, midten af banen gennem livet, sin alders tredivte år. For det er jo også en slags dannelsesroman, vi har at gøre med.

\section{IV}

Men hvordan kunne Oskar vide, hvad der gik for sig i kartoffelmarken? Svaret er: gennem at tromme.

"Det er slet ikke så let at ligge her i den afsæbede metalseng på en anstalt for sindslidende og i synsfeltet fra et glasdækket og med Brunos øje bevæbnet kighul at beskrive røgskyerne fra kaschubiske kartoffelbål og en oktoberregns skråhed. Hvis jeg ikke havde min tromme, der ved dygtig og tålmodig brug kommer i tanker om alt, hvad der er nødvendigt af uvosentligheder for at kunne faste hovedsagen til papiret [min fremhævelse, PM], og hvis jeg ikke havde anstaltens tilladelse til tre-fire timer om dagen at lade mit blik tale, ville jeg være et stakkels menneske uden påviselige bedsteforældre« (p. 20).

At tromme er således - blandt andet - en forudsætning for at skrive, tromning er med andre ord en art kunstnerisk aktivitet. Hen igennem romanen antager denne tromning forskellig karakter, men den almene pointe er, at Oskar er kunstner - romanen er således også en kunstnerroman, som det ofte har været tilfældet med dannelsesromaner.

Men Oskar havde kun tre år til at modnes i. Og det var hans bevidste valg at forblive treårig, eller i al fald ikke at vokse: „Fra begyndelsen stod det mig klart: de voksne vil ikke forstå dig [...]«(p. 54) På sin fødselsdag finder han sig selv ved lugen, der åbner ned til kælderen i faderes butik:

"Der gik dog alligevel et minut, før jeg fattede, hvad faldlemmen til vor lagerkælder krævede af mig. Ved Gud, intet selvmord! Det ville have været for simpelt. Det andet var dog vanskeligt, smertefuldt, krævede et offer og drev allerede dengang, ligesom stedse, når der kræves et offer af mig, sveden frem på min pande« (p. 55). 
Oskar kaster sig ned ad trappen og rammer kældergulvet med hovedet. Da han som følge deraf er holdt op med at vokse, udvikler han sit trommeri:

"Evnen til ved hjælp af en barnebliktromme at kunne fremtromme den nødvendige afstand mellem mig og de voksne viste sig kort efter faldet fra kældertrappen, næsten samtidig med at jeg udviklede en stemme, der gjorde det muligt for mig at synge i så højt et toneleje, at skrige eller synge så skrigende, vedvarende og vibrerende, at ingen vovede at fratage mig min tromme« (p. 56)

Disse skrig viser sig at kunne splintre glas - eller, som nævnt, skære i glas. Oskar er således udstyret med to redskaber til at interagere med sin omverden på afstand. Og dermed altså to måder at udfolde sig kunstnerisk på, i al fald potentielt. Hans brug af disse muligheder skifter igennem romanen: „Af lutter legedrift, idet han forfaldt til en senepokes manierethed, hengivet til l'art pour l'art, sang Oskar glasset ind i sin sjæl og blev ældre derved« (p. 65). Hvilket vil sig så meget som at han forlader den barnlige holdning: han har nået »sin kunsts blomstrings- og forfaldstid« (p. 64).

Denne holdning defineres ganske kort i kapitlet om hans første skoledag, hvor han skriver dette om en lærer: "[hun] stillede sig for et øjeblik an som en ikke usympatisk ældre pige, der glemmer sit pædagogiske kald, smutter ud af den for hende reglementerede eksistenskarikatur og bliver menneskelig, det vil sige barnlig, nysgerrig, dobbeltbundet, umoralsk« (p. 72). At være barnlig har altså ikke noget at gøre med at være uskyldig, bortset fra at det drejer sig om at undgå de voksnes adfærdsformer. Det drejer sig ikke mindst om at gennemskue, hvad der sker i de voksnes verden, at se bag om overfladen, at gennembryde umiddelbare fortolkninger og konventielle iscenesættelser. To scener demonstrerer dette på dels det private, dels det offentlige område.

Den første er en aften hjemme, hvor hans mor og hans officielle far, Matzerath, spiller kort med den mand, Jan Bronski, som er hans mors elsker og formentlig også hans far. Oskar sidder under bordet:

"Jeg befandt mig godt under bordpladen, i ly af den nedhængende dug. Uanfægtet trommende mødte jeg de hænder, der tævede i kortene oven over mig, underordnede mig spillenes forløb og sagde til mig selv efter en lille times skat: Jan Bronski tabte. Han havde gode kort, men tabte alligevel. Intet under, eftersom han ikke passede på. Havde helt andre ting i hovedet end sin ruder. Havde straks ved spillets begyndelse [...] smøget den sorte sko af venstre fod og med gråsokket venstrefod forbi mit 
hovede søgt min mamas knæ - hun sad over for ham - og også fundet det. Knap havde det rørt mama, før hun rykkede nærmere til bordet, så at Jan, der netop blev udfordret af Matzerath og passede ved treogtredive, først løftede hendes kjolesøm med fodspidsen og derefter med hele den fyldte sok, der ganske vist var fra samme dag og næsten ren, kunne vandre mellem hendes lår« (p. 62).

I kapitlet "Tribunen«, er det den offentlige scene, der er tale om. I to omgange, den første drejer sig om en friluftsfremførelse af Wagners Den flyvende hollander ude i skoven. Her er Oskars beretning:

"Et skib bevægede sig mere skovsvinende end sørøvende ud af skoven [...]. Matroser sang til træerne. Jeg faldt i søvn [...] og da jeg vågnede sang matroserne endnu eller matroser påny: "Styrmand, hold vagt«... Men Oskar sov atter ind, glædede sig under indslumringen over, at hans mama var så optaget af Hollænderen, hun gled ligesom på bølger og trak vejret på wagnersk måde. [...] Oskar vågnede (definitivt), fordi der midt i skoven stod en skrigende kvinde ganske alene. Gulhåret var hun og skreg, fordi en belysningsmand blændede og generede hende med en projektør. »Nej!«, skreg hun, »Ve mig!« og »Hvem gør det imod mig?«« (pp. 101-2)

Disse passager demonstrerer den forskudte synsvinkel, synet fra neden. Kortspilsscenen giver også et glimt af, hvordan Oskars synsvinkel inkluderer, hvad der sædvanligvis er udelukket: under den rene borddug kommer vi tæt på Jan Bronskis sokker, som ganske vist her er næsten rene, men muligheden af at de kunne være snavsede og stinkende nævnes, således at en hel verden af ubehagelige sanseindtryk indirekte aktualiseres. Svarende, naturligvis, til den officielle vurdering af forholdet mellem hans mor og Jan Bronski som »snavset«. Det andet eksempel demonstrerer, hvordan prætentioner kan dræbes igennem en fingeret naiv beskrivelse.

Begge disse aspekter er til stede i en central scenes beskrivelse af »Tribunen«, hvor politiske og historiske forhold i mere end én forstand ses fra neden:

"Har De nogensinde set en tribune bagfra? Man burde - blot for at gøre et forslag - gøre alle mennesker fortrolige med synet af en tribune bagfra, inden man samler dem foran tribuner. Den, der nogen sinde har set en tribune bagfra, set den rigtigt, vil fra dette øjeblik at regne være gjort usårlig og uimodtagelig for ethvert trylleri, der i denne eller hin form 
måtte celebreres på tribuner. Noget lignende kan man sige om synet bagfra af kirkelige altre, men det hører hjemme i en anden sammenhæng.

Men Oskar [...] gik fra den grove bagside frem mod det kun til beskuelse fra forsiden beregnede podium, sneg sig med sin tromme, som han aldrig var foruden, når han gik ud, ind mellem støttebjælker, slog hovedet mod en tværstiver i loftet, rev sit knæ på et søm, der på nederdrægtig vis ragende ud af tømmeret, hørte partifællernes støvler og derefter kvindemedlemmernes sko skrabe over sig og nåede endelig derhen, hvor det var mest trykkende og bedst svarede til august måned: foran den indvendige tribunefod fandt han bag et tømmerstykke plads og beskyttelse nok til i ro og mag at kunne goutere den akustiske charme ved en politisk demonstration uden at blive distraheret af faner og visuelt generet af uniformer.

Jeg krøb sammen under talerstolen. Til venstre og højre for mig og over mig stod de yngre trommeslagere fra Jungvolk og de ældre fra Hitlerjugend skrævende og, vidste jeg, med øjne, der var blændet af solskinnet og derfor sammenknebne. Og derpå mængden. Jeg kunne lugte den gennem revnerne i brædderne om tribunen. Folk stod og rørte hinanden med albuer og søndagstøj, folk var kommet til fods eller med sporvognen, folk havde for en dels vedkommende været til fromesse og var ikke blevet tilfredsstillet deraf, man var kommet for at byde sin forlovede, man havde under armen, på noget, man ville være med, når der blev skrevet historie, selv om så formiddagen gik med det«(pp. 108-9).

Oskar specificerer ikke lugten, men den er der. Den detaljerede beskrivelse, som er så karakterstisk for romanen, indbefatter ikke alene sider af tribunens konstruktion, men også mængdens karakter. De ønsker at være en del af historien. At være en del af historien vil sige at blive løftet over sig egen situation, det er opløftende at deltage i et møde som dette. Men der er et forbehold: »selv om det tog hele formiddagen«. Småborgeren identificerer sig ikke fuldstændig med den opløftende historie, den gode frokost kunne være truet. Det skal i øvrigt bemærkes, hvordan parallelstillingen af Wagner-forestillingen og scenen ved tribunen så at sige overfører betydning fra den ene scene til den anden for så vidt som det i et vist omfang er samme behov, der opfyldes: At tage sin forlovede med til et politisk møde fremstilles som noget lignende som at tage sin forlovede med til en Wagner-forestilling - eller at gå i kirke. Men når man erindrer sig Wagners stilling i den National-Socialistiske forestillingskreds, går pointen også den anden vej: operafore-stillinger kan have politiske overtoner, der svarer til tribunesceneriets.

Men Oskar bryder mødet op: 
»Himmelsk letsindigt lod jeg stikkerne spille i mine hænder og lagde med ømhed i håndleddene en kunstfærdig, munter valsetakt på mit trommeblik, en valsetakt, som jeg lod lyde mere og mere indtrængende, og idet jeg fremmanede Wien og Donau, indtil første og anden landsknægttromme ovenpå fandt behag i min vals og derefter også de ældre drenges fladtrommer mere eller mindre behændigt optog min rytme. Imellem dem fandtes der dog også ubønhørlige personer, der ikke havde noget gehør, og som blev ved med at slå bumbum og bumbumbum, mens jeg ville have trefjerdedelstakten, som er så populær i folket. [...] $\mathrm{Og}$ folket takkede mig. [...] Kun Löbsack [...] havde mærkeligt nok ikke sans for valsetakten.Han var vant til at blive sluset til tribunen med snorlige marchmusik. Disse letsindige klange berøvede ham nu troen på folket» (pp. 109-10).

Oskar skifter nu til Jimmy the Tiger, en charleston -»Og de, der endnu ikke dansede på Maiwiese, greb, før det var for sent, de sidste damer, der var at få." (p. 110) Han har ødelagt mødet. Dets appel til "folket " kunne ikke matche den appel, der udgik fra waltz og charleston - senere skulle det blive anderledes, må man så huske på. Men hvad var Oskars hensigt? Var han »en modstandskæmper" (p. 113)? Svaret er, at hans indsats var "destruktiv" (ibid.), den var rettet imod alle slags symmetri, uniformer og bevægelser. Det er med andre ord en barnlig reaktion, som er hinsides moral: "Hvad der end blæste, sang, bad eller forkyndte: min tromme vidste det bedre« (ibid.).

\section{$V$}

Værre forhold er på tale i senere episoder. Det tilsyneladende uskyldige ønske om at være til stede, hvor der skabes historie, bliver til faktiske historiske handlinger. Et eksempel er Meyn, trompetisten: »Til at begynde med havde jeg nu og da held med mig hos trompetist Meyn. Når han lå fuld på tørreloftet under lagnerne, kunne han blæse overmåde musikalsk i sin trompet og være til glæde for min tromme« (p. 158). Men musikalsk talent og følelse er ingen garanti for nogetsomhelst (her er det givetvis helt på sin plads at erindre, hvordan kunstnerisk talent blandt Grass' ældre kolleger ikke hindrede sympati for National-Socialismen). "I maj 38 opgav han at drikke machandel og sagde til alle mennesker: "Nu begynder der et nyt liv! « Han blev medlem af den ridende SA afdelings musikkorps. Med lange støvler, buksebag af læder og aldeles ædru så jeg ham fra da af tage fem trin ad gangen på trappen« (ibid.). Da hans gamle ven dør, vil Meyn spille trompet 
ved hans begravelse og tager sin frakke over uniformen. Denne historie fortælles i det sidste kapitel i første del af romanen, som har titlen »Tro Håb Kærlighed«. Her forvandles fortællingen til et eventyr, der langsomt lader begivenhederne skride frem igennem en serie af gentagelser med små variationer, som bringer nye momenter ind i beretningen:

"Der var en gang en SA-mand, der beholdt sin civile frakke over sin uniform fra de ridende SA, mens han stod ved sin ungdomsvens grav og blæste dejligt og machaldelklart på trompeten. Da omtalte Schugger Leo, der findes på alle kirkegårde, ville kondolere følget, fik også alle Schugger Leos kondolence at høre. Kun SA-manden måtte ikke tages Leos hvide handske, fordi Leo genkendte SA-manden, var bange for ham og højt skrigende trak handsken til sig uden kondolence. Men SA-manden gik hjem uden kondolence og med kold trompet, hvor han fandt sine fire katte i sin lejlighed under taget $\mathrm{i}$ vor beboelsesejendom.

Der var en gang en SA-mand, der hed Meyn. Fra en tid, hvor han daglig havde drukket machaldel og havde blæst dejligt på trompet, havde Meyn i sin lejlighed fire katte, af hvilke den ene hed Bismarck« (pp. 180-81)

Og således bliver det ved og ved. Denne beretning i slow motion er motiveret af stoffet: i dette kapitel går Grass direkte ind på én af den historiske udviklings afgørende begivenheder. Det kræver distance. Eventyrtonen er ét af midlerne. Det berettes nu, hvordan Meyn dræber sine katte og bliver kastet ud af SA "på grund af uværdig adfærd« (p. 183). Og så følger kapitlets centrale emne:

"Selv da SA-manden natten mellem den 8. og 9. november 1938, som man senere kaldte for Krystalnatten, udviste særligt mod og sammen med andre stak Langfuhr-synagogen på Michaelisweg i brand og også medvirkede energisk, da flere forinden nøje betegnede forretninger skulle ryddes, kunne al hans iver ikke forhindre, at han blev ekskluderet af det ridende SA. For umenneskeligt dyrplageri blev han degraderet og strøget af medlemslisten« (ibid.).

I dette kapitel anvendes en række midler til at nærme sig de National-Socialistiske aktiviteter ved siden af eventyrtonen og gentagelsesstrukturen. I det netop citerede er midlet bl.a. imitationen af eller ekkoer fra nazi-retorik: "udviste særligt $\bmod «$, , medvirkede energisk«, "umenneskeligt dyrplageri«.

I det følgende afsnit er Oskar direkte involveret for så vidt som hans far tager ham med for at tage del i aktiviteterne: 
»Der var en gang en købmand, der en dag i november lukkede sin forretning, fordi der var noget på færde i byen: han tog sin søn Oskar i hånden og kørte med linie fem til Langgasser Tor, fordi synagogen dér brændte, ligesom tilfældet var i Zoppot og Langfuhr. Synagogen var næsten nedbrændt, og brandvæsenet passede på at ilden ikke bredte sig til de andre huse. Foran ruinen slæbte uniformerede og civilister bøger, hellige brugsgenstande og besynderlige stoffer sammen. Bunken blev stukket i brand, og købmanden benyttede lejligheden og varmede sine fingre og sine følelser over den offentlige ild. Men hans søn Oskar, der så faderen så optaget og opflammet, stak ubemærket af [...]«(p. 183).

Her opfører faderen sig på samme måde som mængden i Tribune-kapitlet: han griber lejligheden til at varme sin følelser ved en offentlig begivenhed. Kontinuiteten i holdningen trods den radikalt anderledes karakter af situationen er en hovedpointe i skildringen af almindelige menneskers rolle i National-Socialismens udfoldelse.

Blandt de forretninger, som angribes, er Sigismund Marcus' legetøjsforretning, som Oskar har sine blik-trommer fra:

»De, de samme fyrværkere, som jeg, Oskar, mente at være løbet fra, havde allerede før jeg besøgt Markus, havde dyppet pensler i farve og tværs over butiksruden skrevet, med gotisk skrift, ordet Jødesvin, og derefter måske af misfornøjelse med deres egen håndskrift, sparket ruden ind med deres støvlehæle [...]. Uden at ænse døren var de gået ind i butikken gennem vinduet og legede nu derinde med børnelegetøjet på deres utvetydige måde« (p. 184).

Igen toner den barnlige synsvinkel beskrivelsen af begivenhederne ned, således at det bliver muligt at bringe de historiske kendsgerninger videre til læserne på en måde, der på én gang undgår moraliserende patos og involverer den ganske almindelige læser. »Jeg fandt dem ved legen, da jeg ligeledes tråte gennem vinduet ind i butikken. Nogle havde smøget bukserne ned og trykket brune pølser, i hvilke man endnu kunne se halvt fordøjede ærter, ud på sejlskibe, violinspillende aber og på mine trommer« (ibid.) Disse ærter er det afgørende element her: de genkalder en hel dagliglivsverden og antyder, hvordan disse mænd for ikke så længe siden nød deres ærtesuppe, eller hvad det nu kan have været, hjemme hos sig selv. Der er tale om en mængde af ganske almindelige mennesker, der - som det blev formuleret i Tribunekapitlet - »ville være med, når der blev skrevet historie«. Historien skabes af ganske almindelige ærtespisende mennesker. „De lignede allesammen musiker Meyn, bar Meyns uniform, men Meyn var der ikke, ligesom jo også 
de, der var med her, ikke var med andre steder« (ibid.). Denne raffinerede sætning udnytter igen den barnligt-naive tilgang, men den implicerer endnu en gang - det helt afgørende forhold, at det som sker er resultatet af individuelle handlinger, af enkeltpersoners handlinger. Ingen er alle steder, naturligvis, ingen enkeltperson er ansvarlig for den historiske begivenhed som sådan. Men man kan varme sine følelser ved ilden, mens de enkelte handlinger tilsammen skaber historie. Schugger Leo havde god grund til at trække sig tilbage fra Meyn. Legetøjshandleren Markus begår selvmord, da hans vinduer bliver smadret.

Kapitlet og dermed første del af romanen afsluttes med yderligere to eventyrformler: „Der var en gang en legetøjshandler, der hed Markus, og han tog alt legetøj med sig ud af denne verden. / Der var en gang en musiker, der hed Meyn, og hvis han ikke er død, så lever han endnu og blæser igen så dejligt på trompet« (p. 187).

Begivenhederne og det som fulgte repræsenterede en irreversibel historisk vending (der er ikke længere noget legetøj), men de tvetydige menneskelige muligheder er fortsat vores betingelser.

\section{VI}

I sin radioanmeldelse af Bliktrommen pegede Hans Magnus Enzensberger på udviklings- og dannelsesromanen som traditionsbaggrund, men romanen havde selvfølgelig, som Grass også selv understregede, »et ironisk-distanceret forhold til den tyske dannelsesroman «": Oskar ønsker jo netop ikke at vokse op, at modnes. En særlig type dannelsesroman er kunstnerromanen. Også her har Bliktrommen et særegent forhold til traditionen. Der er i romanen tale om »det guddommelige, men også det absolut dæmoniske i [Oskars] geni« (p. 156), der er præget af en vis »karakteristisk, pludselig frembrydende heftighed« (ibid.). Grass refererer her formentlig til Thomas Manns Doktor Faustus og dens hovedperson, Adrian Leverkühn, som trådte i kontakt med en Mefisto-lignende, diabolsk figur. Men hvor forskellig er Oskar ikke fra den nietzscheanske Adrian. Der er en betydelig afstand mellem Mann og Grass, en generationsafstand, men også en kulturel afstand i den forstand, at Mann forholder sig til personer fra en kulturel, repræsentativ elite, mens Grass henter sine figurer fra de lavere lag, fra småborgerskabet, som han selv henviste til. Og mens Manns ironi er en ironi fra oven, er Grass' satire forbundet med blikket fra neden.

5. Heinz Ludwig Arnold: "Gespräche mit Günter Grass«, in: Text+Kritik, Heft 1/la, München 1978, p. 6. 
Han understregede selv en endnu mere væsentlig forbindelse til traditionen: „Bogen har nært slægtskab med [...] den europæiske romantradition, som med alle dens omveje og svinkeærinder hidrører fra pícaro-romanen [...] og der er Grimmelshausens roman den første store. «"

Den Eventyrlige Simplicissimus, Tysk var titlen på Grimmelshausens roman fra 1668, undertitlen giver lidt af indholdet: »Der er: Beskrivelsen af en sælsom vagant/ ved navn Melchior Sternfells von Fuchshaims liv/, hvor og hvordan han nemlig kom til denne verden/ hvad han i den har set/ lært/ erfaret og udholdt/ også hvorfor han igen frivilligt forlod den./ Overalt lystig/ og mandigt nyttig at læse.«Simplicius summerer hen imod slutningen af romanen (slutningen af femte bog) sit liv med få ord:

„Da jeg efter min rigtige fars salige død kom til denne verden, var jeg enfoldig og ren, retsindig og hæderlig, sanddru, ydmyg, beskeden, mådeholden, kysk, blufærdig, from og andægtig, men blev snart ondskabsfuld, falsk, forløjet, hoffærdig, urolig og tilmed helt ugudelig, hvilke laster jeg alle sammen lærte uden nogen læremester. $\iota^{7}$

Under indtryk af læsningen af Antonio de Guevara beslutter han at trække sig tilbage fra verden. Det sidste kapitel består overvejende af et langt citat fra den spanske forfatter de Guevara, som har dette barok-tonefald:

„Far verden, far vel! Thi hos dig er intet bestandigt. De høje tårne rammes af lynet, møllerne føre bort af vandet; tømmeret ædes af ormene, kornet af mus, frugterne af larver og klæderne af møl; køerne fordærves af alderdom og det stakkels menneske af sygdom. $\ll^{8}$

Fra begyndelsen til enden er Simplicius vidne til 30års krigens rædsler, romanen er skrevet fra den tilbagetrukne Simplicius' synsvinkel på grundlag af hans oplevelser som overvejende underdog.

Lighederne med Bliktrommen falder i øjnene. Ikke alene når det gælder stof, men også formelt: en førstepersons fortæller gør rede for sit liv fra en tilbagetrukket position. Men der er selvfølgelig også vigtige forskelle. Simplicius skriver fra en religiøst from position, og hans liv har været en række desillusioner. Oskar skriver fra en position i en anstalt, han er blevet indsat i, men ganske vist ikke ønsker at forlade, og hans liv kunne ikke blive desillusionerende, eftersom han aldrig havde nogen illusioner:

6. Ibid.

7. H. J. C. Grimmelshausen: Den eventyrlige Simplicissimus, København 1963, bd.III, p. 71.

8. Op.cit., p. 73. 
"Jeg så dagens lys i skikkelse af to treswattsglødelamper. [...] Lad det være sagt med det samme: jeg hørte til de finthørende spædbørn, hvis åndelige udvikling er afsluttet allerede ved fødslen og fra da af kun bekræfter sig selv. Lige så upåvirkeligt jeg som foster kun havde hørt på mig selv og interesseret mig for mig selv, lige så kritisk lyttede jeg nu til mine forældres første spontane ytringer under glødelamperne. [...] Ja, det, jeg fik ind gennem øret, vurderede jeg straks med den lille bitte hjerne og besluttede efter at have overvejet alt det hørte tilstrækkeligt at gøre dette og hint og lade andet stå ugjort. [...] Ensom og uforstået lå Oskar under glødelamperne, sluttede at det ville blive ved med at være sådan, indtil tres-halvfjers år senere en definitiv kortslutning ville afbryde strømmen til alle lyskilder, og tabte derfor lysten, før dette liv under glødelamperne begyndte [...]«(pp. 40-1, 42).

Grimmelshausens roman var inspireret af den spanske pícaro-roman. Den første af dem var den anonyme Lazarillo de Tormes fra 1554. I prologen til denne roman henvender forfatteren sig - som det var kotyme - til en vis "Deres Nåde«(Vuestra Merced), som i et brev har bedt ham om »detaljeret« (muy por extenso) at fortælle sin Historie (el caso, dvs 'sagen' eller emnet for den fingerede brevveksling mellem forfatteren og 'Deres Nåde', Francisco Rico diskuterer disse formuleringer i sin udgave af bogen) - og »så må jeg hellere starte med Begyndelsen, ikke midtvejs, således at De kan vide alt om mig“ (porque se tenga entera noticia de mi persona). Hvem er denne »Deres Nåde«? Lazarillo ender - så langt beretningen går - med at være by-udråber og drager fordel af i kraft af sit job at være mellemmand i en lang række handelsaktiviteter. Desuden har han giftet sig med en kvinde, som har været i huset hos »Ærkepræsten ved St Salvador«, et arrangement som tydeligvis involverer at hans kone er denne ærkepræsts elskerinde (vi er i et katolsk land, skal vi huske, selv om den slags trekantshistorier jo er udbredt i datidens fortællelitteratur). Erkepræsten er 'Deres Nådes Tjener og Ven', bemærker Lazarillo som en slags argument for ægteskabet. Redegørelsen for Lazarillos liv synes således skrevet til en høj person, måske en, der har del i det kirkelige system, som igennem Lazarillos bestræbelse på at »lade ham vide alt« informeres om, at en af hans underordnede (»Tjener«) - som også er hans ven - har arrangeret dette liv sammen med sin tidligere tjenestepige, som legitimeres af hendes ægteskab med Lazarillo. Ved at fortælle alt dette om sig selv fortæller Lazarillo 'Deres Nåde' om dennes vens gøren og laden. Hvis ideen om at 'fortælle alt' er modelleret over bekendelsen og skriftemålet som institutionelt organiseret blotlæggelse af syndefuld adfærd, eller over vidnesbyrdet i en retssag (jf. el caso: sagen) så betyder det, at den 
person der er i position til at lytte til skriftemålet eller vidnesbyrdet, dvs. 'Deres Nåde', bringes i denne mærkværdige situation: bekendelsen informerer ham om hans ven og underordnedes syndefulde, normstridige adfærd. Og det betyder, at Lazarillo - gennem at 'fortælle alt' - har immuniseret sig imod bebrejdelser fra 'Deres Nåde'. Dette er, naturligvis, altsammen fiktivt, men jo så også netop rammen for fiktionen. Implikationen er en medskyldigheds-relation mellem fortcelleren og loserne af, hvad han kalder »denne Bagatel, som jeg skriver i min plumpe Stil«, "denne fattige Bog«, ${ }^{9}$ hvor der berettes om »Barnagtigheder ${ }^{10}{ }^{10}$

Bliktrommen er skrevet af Oskar fra en position i en mental-anstalt. Også han starter med begyndelsen, og han fortæller meget, om ikke alt. Her er læserens position ikke den samme som den at lytte til et skriftemål, men det er en relation, som ligner den mellem Lazarillo og 'Deres Nåde': hans lasere har på den ene eller anden anden måde taget del $i$ de historiske begivenheder, hans beretning eksemplificerer.

Både Lazarillo og Simplicius er således en slags forfædre for Oskar. De to gamle romaner hører hjemme i en tradition, som Grass følger op. Slægtskabet går som vist videre end blot til dette, at der er tale om en vagant, en pícaro. Det har ikke alene at gøre med beretterens situation som den, der bærer vidnesbyrd nedefra, det har også - og helt fundamentalt - at gøre med berettersituationen, læserens, modtagerens involvering og medansvar.

\section{VII}

Bliktrommen indskriver sig således i en særlig tradition i den europæiske roman og ikke blot i den europæiske romantradition som sådan. Som understreget af Grass er der nok tale om en - ironisk distanceret - forbindelse til dannelses- og kunstnerromanen, men det er pícaro-romanen, der er den afgørende forbindelse, formelt og tematisk, indholdsmæssigt. Dette valgslægtskab modsvares af Grass' distance til samtidens romandiskussioner. Få sider inde i Bliktrommen kommenterer Oskar disse diskussioner:

"Man kan begynde en historie i midten og anstifte forvirring, idet man dristigt vandrer enten fremad eller baglæns. Man kan stille sig moderne an, stryge alle tids- og afstandsangivelser og bagefter forkynde eller lade forkynde, at man endelig, i sidste øjeblik, har løst problemet om tid og rum. Man kan også straks ved begyndelsen hævde, at det nu til dags er

9. Lazarillo de Tormes Levned hans Oplevelser og Genvordigheder, København 1945, p. 6.

10. Op.cit., p. 14. 
umuligt at skrive en roman, men derpå, så at sige bag ryggen af sig selv, skrive en gammeldags handlingsroman for til sidst at fremstå som den sidste mulige romanforfatter. Jeg har også ladet mig fortælle, at det ser pænt og beskedent ud, hvis man i begyndelsen erklærer, at der ikke længere findes romanhelte, fordi der ikke længere findes individualister, fordi individualiteten er gået tabt, fordi mennesket er ensomt, hvert menneske lige ensomt, uden ret til individuel ensomhed, og danner en navn- og helteløs ensom masse. Det kan alt sammen være meget rigtigt« (p. 13).

Der er utvivlsomt mange referencer impliceret her, heriblandt sociologen David Riesmanns Det ensomme massemenneske, som var udbredt dengang. Grass kan også her have tænkt på artikler, som senere indgik i Robbe-Grillets $P a ̊$ vej mod en ny roman (Pour un nouveau roman, 1963) - som f.eks. "Om nogle forældede begreber" fra 1957, eller i Roland Barthes Essais critiques (1964), han boede jo i Paris, men han kunne for den sags skyld også have læst oversatte bidrag af Barthes og Robbe-Grillet i det centrale tyske tidsskrift Akzente. ${ }^{11}$ I den nævnte artikel slår Robbe-Grillet fast, at det er blevet umuligt at fortælle, ${ }^{12}$ og han mener »forlængst [at have] hørt nok om "personerne« (» $\mathrm{Om} «$, p. 26$)$ : »Personromanen hører ganske enkelt fortiden til, den karakteriserer en epoke, nemlig den hvor individet nåede sit højdepunkt. - - Romanen synes at vakle efter at have mistet sit førhen sikre støttepunkt, helten. Hvis den ikke kommer på fode igen, er det, fordi den hørte sammen med en samfundsform, som nu er rundet ud« (»Om», pp. 28, 29).

Enzensberger tog spørgsmålet op i sin anmeldelse: „Grass benytter således et traditionelt romanmønster og opviser nogle af den traditionelle romanforfatters dyder. Endnu engang er teorierne om romanens krise, om plottets ophør, om opløsningen af romanfigurerne blevet dementeret. Grass kan uden større besvær give afkald på de nyeste litterære omvendelser, nouveau roman skolen, beat generationen og dens snitmønsterark. $\|^{13}$

Men faderfiguren Adorno kan også være på tale her. Her er en passage fra hans essay om »Fortællerens stilling i samtidens roman« fra 1954:

11. Akzente (1956), pp. 303-7 og 316-19.

12. Alain Robbe-Grillet: „Om nogle forældede begreber«, in: På vej mod en ny roman, Fredensborg 1995, p.32. Herefter forkortet »Om».

13. Hans Magnus Enzensberger: „Wilhelm Meister auf der Blechtrommel«, in F. J. Görtz (ed): "Die Blechtrommel«. Attraktion und Ärgerniss. Ein Kapitel deutscher Literaturkritik, Darmstadt und Neuwied 1984, p. 68. 
»Erfaringens identitet, livet der i sig selv er kontinuerligt og artikuleret, som er forudsætningen for fortællerens holdning, er gået i forfald. Man kan blot erindre sig, hvor umuligt det ville være for én, der tog del i krigen, at fortælle om den, sådan som man tidligere kunne fortælle om sine eventyr. Med rette mødes den fortælling, der optræder som om fortælleren kunne beherske en sådan erfaring, men utålmodighed og skepsis blandt modtagerne. [...] At fortælle noget vil jo sige: at have noget særligt at fortælle, og netop dette forhindres af den forvaltede verden, af standardisering og af det bestandigt ensartede. Forud for alt indhold er allerede fortællerens prætention ideologisk, som om verdens gang endnu var individuationens, som om individet endnu med sine stemninger og følelser kunne forbinde sig med skæbnen, som om den enkeltes indre endnu umiddelbart formåede noget: $[\ldots] . \|^{14}$

Det er let at se, hvordan Günter Grass' romanprojekt er langt fra Adornos skildring af romanens og fortællerens situation, - ligesom det er let at se, hvordan Adornos ræsonnement er nært knyttet til den romantradition, som Grass forholder sig distanceret til, såvel den som Adorno ikke længere finder mulig (dannelsesromanen og dens forlængelser), som den der i negation af den førstnævnte efter Adornos ræsonnement måtte være den historisk adækvate.

Det er da værd at overveje, om ikke hele Adornos begrebslige ramme og dermed den tradition han ligger i forlængelse af - radikalt udfordres af romaner som Bliktrommen - og Salman Rushdies Midnatsbørn, som var inspireret af netop Bliktrommen og har en række træk til fælles med Grass' roman.

Det centrale værk i den tradition, som Adorno repræsenterer, er Georg Lukács Romanens teori fra den første verdenskrigs tid. Det er, som undertitlen angiver, et historiefilosofisk essay om den store epiks former. Den centrale historiske fortolkning er, at »romanens form er [...] udtryk for den transcendentale hjemløshed. ${ }^{15}$ Romanen tilhører en tidsalder, »for hvilken livets ekstensive totalitet ikke længere er givet for den umiddelbare forståelse, for hvilken meningens indre tilstedeværelse i livet er blevet til problem, og som alligevel som livsholdning søger totalitet« (TdR, p. 53). Transcendens, totalitet og indre mening i livet hænger ikke længere sammen, som de efter Lukács' opfattelse gjorde i den græske antik, men der er stadig tale om en længsel efter meningsfuld totalitet eller helhed, altså læng-

14. Theodor W. Adorno: "Standort des Erzählers im zeitgenössischen Roman«, in: Noten zur Literatur I, Frankfurt am Main 1968, pp. 62-3. Herefter forkoret »SdE«.

15. Georg Lukács: Die Theorie des Romans, Neuwied und Berlin 1965, p. 35. Herefter forkortet $T d R$. 
sel efter eller fordring på en tilværelse, som i sig selv er meningsfuld og samtidig ser denne meningsfuldhed i sammenhæng med en højere mening, en mening, der beror på principper som ligger hinsides den menneskelige livssfære. Som ung skrev Lukács i sin dagbog, at hvis ikke hans liv var væsentligt, ville selvmord være den eneste konsekvente handling. I Romanens teori er der et ekko af denne livsstemning i beskrivelsen af det græske epos: »Væren og skæbne, eventyr og fuldendelse, liv og væsen er da identiske begreber. For spørgsmålet, som epos'et opstår som formende svar på, er: hvordan kan livet blive væsentligt« (TdR, p. 23). Forholdet mellem 'skæbne' og individuel erfaring - «denne handlingernes overensstemmelse med sjælens indre fordringer« (ibid.) - var også Adornos anliggende for så vidt som de nu efter hans opfattelse var splittet fra hinanden: "som om individet endnu med sine stemninger og følelser kunne forbinde sig med skæbnen«, skrev han. »Liv og væsen«, termerne kan synes fjerne, men de er involverede i Adornos prosa, som kun til dels er forskellig fra Lukács':

»Ikke blot dette, at alt positivt, håndgribeligt, også det indres fakticitet, er blevet beslaglagt af information og videnskab, tvinger romanen til at bryde med det og overgive sig til fremstillingen af væsenet eller uvæsenet, men også dette, at jo tættere og ubrudt den samfundsmæssige livsproces' overflade føjer sig sammen, desto mere hermetisk skjuler den som et slør væsenet. Vil romanen vare tro mod sin realistiske arv og sige, hvordan det virkelig forholder sig, må den give afkald på en realisme, der, idet den reproducerer overfladen, kun hjolper denne $i$ dens bedrageriske virksomhed« (»SdE«, p. 64, Adornos kursivering).

Væsen er blevet uvæsen, det væsentlige er uvæsentligt. Dette paradoks har at gøre med, at "væsen« anvendes i to forskellige betydninger. Den umiddelbare betydning stammer fra Marx' forvandling af Hegels begrebsaparat. I denne sammenhæng er 'væsen' den indre sammenhæng, det indre princip i kapitalistiske samfundsforhold, et princip som tilsløres af den måde sådanne samfundsforhold træder frem på, præsenterer sig på, umiddelbart tager sig ud (nemlig - på hegeliansk - fremtræden i modsætning til væsen, Erscheinung modsat Wesen). Tingsliggørelse (Verdinglichung) er effekten af det sociale system: enkeltmenneskene, individerne, rives fra hinanden og tendensen er, at de bliver til rene funktioner i den sociale mekanik. Men eftersom denne kapitalistiske form, kapitalismens 'væsen', af Adorno karakteriseres som 'uvæsen', 'Unwesen', er det impliceret, at et andet 'væsen' kan tænkes, et sandt væsen, det som er fuldstændig forskelligt fra verden, som den er i kapitalistisk regi. 
Dette kan tage sig ud som abstrakt begrebsgymnastik, men det drejer sig om det grundlæggende i Adornos ræsonnement. Tingsliggørelse er det centrale begreb for effekten af den kapitalistiske samfundsform. Denne tingsliggørelses yderste effekt var for Adorno, hvad der signaleres med Hiroshima og Auschwitz. I hans essay om Slutspil, som også er fra omtrent samme tid som Bliktrommen, er det dette begrebsapparat, der ligger til grund for analysen af Becketts historiske, for ikke at sige historiefilosofiske betydning. Slutspil repræsenterer for Adorno den historiefilosofisk adækvate dramatiske form, dvs. den form, der korresponderer med Adornos opfattelse af den historiske epoke.

Mit udgangspunkt var, at Slutspil og Bliktrommen er omtrent samtidige. Min pointe er, som det vil være fremgået, at disse to samtidige stykker litteratur er fundamentalt forskellige, og at en kritisk-analytisk refleksionsramme, der kan synes adækvat i det ene tilfælde, er helt ved siden af i det andet tilfælde. Man kommer ikke langt med Bliktrommen, hvis man tager udgangspunkt i tingsliggørelse som analytisk nøgle. Ej heller vil man have nogensomhelst chance for at gribe denne romans væsentligste aspekter, hvis man tager den som endnu et eksempel på transcendental hjemløshed.

Lukács' Romanens teori forsøger at indfange de væsentlige sider af romanen. Hans eget - meget kritiske - forord til nyoptrykket fra 60erne gør opmærksom på, at »der ikke var plads til romanforfattere som Defoe, Fielding eller Stendhal i denne skematik; at forfatteren af Romanens teori med 'syntetiserende' vilkårlighed stillede betydningen af Balzac og Flaubert, af Tolstoj og Dostojevskij på hovedet« - den ældre Lukács satte mere pris på Balzac og Tolstoj. Men i forbindelse med Bliktrommen er det oplagt, at der er endnu flere problemer med Lukacs' historiske konstruktion i Romanes teori: pícaro-traditionen er fuldstændig fraværende, Grimmelshausen er ikke nævnt, desuden er eksempelvis Rabelais - et andet af Grass forbilleder - fraværende.

I det bredere romanhistoriske og romanteoretiske perspektiv peger Bliktrommen på en anden udgave af romanens genealogi, hvor den spanske pícaro-roman bliver central. Grass roman er således en udfordring for litteraturhistorien - og for litteraturteorien. Oskar er ikke så meget en problematisk ung mand, der konfronteres med en borgerlig, tingsliggjort verden som han er en selvvalgt barnlig figur, der bærer vidnesbyrd om en småborgerlig verden og dens udvikling gennem National-Socialismen til en ny Biedermeier, en verden som gennem individuelle smålige handlinger skabte en historisk katastrofe af hidtil usete dimensioner - snarere, kunne man tilføje, end en tingsliggjort verden, der ud fra en indre, væsentlig logik skabte katastrofen. 


\section{VIII}

Grass vender tilbage til Adorno i sin Nobelpris-tale: "Adornos skrift på væggen har bevaret sin kraft til i dag. Alle min generations forfattere har kæmpet med den. Ingen ønskede eller kunne forblive tavse. Det var vores pligt at tage gåsegangen ud af det tyske sprog, at lokke det ud af dets idylliseringer og tågede inderlighed. Vi, børnene som havde brændt fingrene, det var os, der måtte afvise absolutterne, det ideologisk sort-hvide. Tvivl og skepticisme var vore gudfædre og de talrige nuancer i gråt deres dåbsgave til os. ${ }^{16}$ Grass var således involveret i to typer generationskonflikt: på den ene side med intellektuelle forældre, hvoriblandt Adorno, på den anden side som en af dem, der havde brændt fingerne - med hans forældres generation. Han forbinder disse to spørgsmål i én sætning i sin Nobelpris-tale: »Den eneste måde man kunne skrive efter Auschwitz var, hvad enten der var tale om prosa eller poesi, ved at blive erindring og forhindre fortiden $\mathrm{i}$ at høre op. ${ }^{17}$

16. Günter Grass: „Fortsetzung folgt...» (Nobelpris-tale), PMLA 115 (2000:3) (engelsk oversættelse), p. 297, 2.

17. Ibid. 